Article

\title{
Simulation of the Operation of a Spark Ignition Engine Fueled with Various Biofuels and Its Contribution to Technology Management
}

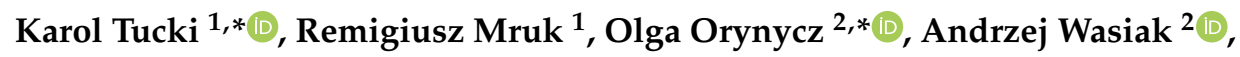 \\ Katarzyna Botwińska ${ }^{1}$ and Arkadiusz Gola ${ }^{3}$ (D) \\ 1 Department of Organization and Production Engineering, Warsaw University of Life Sciences, \\ Nowoursynowska Street 164, 02-787 Warsaw, Poland; remigiusz_mruk@sggw.pl (R.M.); \\ katarzyna_botwinska@wp.pl (K.B.) \\ 2 Department of Production Management, Bialystok University of Technology, Wiejska Street 45A, \\ 15-351 Bialystok, Poland; a.wasiak@pb.edu.pl \\ 3 Institute of Technological Information Systems, Faculty of Mechanical Engineering, \\ Lublin University of Technology, Nadbystrzycka 38 D, 20-618 Lublin, Poland; a.gola@pollub.pl \\ * Correspondence: karol_tucki@sggw.pl (K.T.); o.orynycz@pb.edu.pl (O.O.); Tel.: +48-746-98-40 (O.O.)
}

Received: 15 April 2019; Accepted: 10 May 2019; Published: 16 May 2019

\begin{abstract}
Economic progress, development of transport, production of new cars, production of more and more energy, and the combustion of fossil fuels are causing huge changes that are currently occurring in the environment. Ecological problems of the contemporary economy combined with perspectives of resources exhaustion, as well as the need to follow sustainable rules of living, require the search for new fuels. Fuels which can assure their availability and good environmental performance are needed for maintaining sustainable transportation. Knowledge about the behavior of various fuels is necessary for realistic methods of technology management in transportation means and the fuel industry. This paper describes biofuels that can be an addition to petrol or can exist as standalone fuels. A simulation was carried out on an urban vehicle and the tested fuels were petrol 95, ethanol, methanol, and dimethyl ether. For the selected engine a simulation corresponding to that of the New European Driving Cycle (NEDC) test was created using the Scilab package. Based on this simulation, values of carbon dioxide and water vapor emission were determined. The fuel demand for each fuel mixture and the amount of air for the fuels used were also calculated (and verified on the basis of laboratory tests). It was demonstrated that addition of biofuel decreases emission of carbon dioxide, simultaneously increasing emission of water vapor. Biofuel additive also caused an increase in fuel consumption. Unfortunately, in the New European Driving Cycle test being investigated, carbon dioxide emissions in all cases exceeded the permissible level of $130 \mathrm{~g} \mathrm{CO}_{2} / \mathrm{km}$, which is bad news in the context of the further tightening of norms and standards. The simulation tests confirmed that when using the start/stop system and applying specific additives, the carbon dioxide emission decreases and the consumption of mixtures with the activated start/stop system is smaller. The analyzed problems and results of this analysis become more important in light of the Worldwide Harmonized Light Duty Vehicles Test Procedure (WLTP) standard, which became binding from September 2018 and applies to the sale of cars that had been approved prior (in accordance with the New European Driving Cycle standard). Although the NEDC standard appears obsolete the computer model simulating this type of test will be necessary in many cases. It is, however, needed and possible to develop a similar simulation procedure for WLTP tests.
\end{abstract}

Keywords: biofuels; emission standards; vehicle test; exhaust emission; simulation; fuel production management 


\section{Introduction}

The following list contains a collection of the most important quantities used in the calculations in this work, together with appropriate symbols and units (Table 1).

Table 1. Symbols and units used in calculations.

\begin{tabular}{|c|c|c|}
\hline Symbol & Description & Unit \\
\hline Zap & air demand constant for the fuel mixture & {$\left[g_{\text {air }} / g_{\text {fuel }}\right]$} \\
\hline Zap $_{95}$ & air demand constant for petrol $95^{\mathrm{A}}$ & {$\left[\mathrm{g}_{\text {air }} / \mathrm{g}_{\text {fuel }}\right]$} \\
\hline $\mathrm{Zap}_{d}$ & air demand constant for the additive & {$\left[\mathrm{g}_{\text {air }} / \mathrm{g}_{\text {fuel }}\right]$} \\
\hline$u$ & mass fraction of the additive in the mixture & {$\left[g_{\text {biofuel }} / g_{\text {mixture }}\right]$} \\
\hline$O p$ & calorific value for the fuel mixture & {$[\mathrm{kJ} / \mathrm{g}]$} \\
\hline$O p_{95}$ & calorific value for petrol $95^{\mathrm{B}}$ & {$[\mathrm{kJ} / \mathrm{g}]$} \\
\hline$O p_{\mathrm{d}}$ & calorific value for the additive & {$[\mathrm{kJ} / \mathrm{g}]$} \\
\hline$v(t)$ & momentary speed of the vehicle in the test & {$[\mathrm{m} / \mathrm{s}]$ or $[\mathrm{km} / \mathrm{h}]$} \\
\hline$t k$ & end time of simulation & {$[\mathrm{s}]$} \\
\hline$a$ & vehicle acceleration & {$\left[\mathrm{m} / \mathrm{s}^{2}\right]$} \\
\hline$F k$ & moment value of force on wheels & {$[\mathrm{N}]$} \\
\hline$R$ & wheel radius & [m] \\
\hline$P m$ & power transmission ratio for torque ${ }^{C}$ & {$[-]$} \\
\hline$P \omega$ & drivetrain ratios for rotational speed $\mathrm{D}$ & {$[-]$} \\
\hline$M p$ & momentary torque value on vehicle transmission & {$[\mathrm{N} \cdot \mathrm{m}]$} \\
\hline$\omega p$ & instantaneous speed value on vehicle transmission & {$[\mathrm{rad} / \mathrm{s}]$} \\
\hline$f u$ & hourly fuel consumption function dependent on speed and torque & {$[\mathrm{g} / \mathrm{h}]$} \\
\hline we & rotational engine speed & {$[\mathrm{rad} / \mathrm{s}]$} \\
\hline $\mathrm{Me}$ & engine torque & {$[\mathrm{N} \cdot \mathrm{m}]$} \\
\hline fuel & fuel flux & {$[\mathrm{g} / \mathrm{s}]$} \\
\hline air & air flux & {$[\mathrm{g} / \mathrm{s}]$} \\
\hline$\dot{E e}$ & energy flux supplied by the fuel & {$[\mathrm{J} / \mathrm{s}]$} \\
\hline$\eta$ & efficiency & {$[-]$} \\
\hline
\end{tabular}

Economic progress, development of transport, production of new cars, production of more and more energy, and the combustion of fossil fuels are causing huge changes that are currently occurring in the environment [1,2]. Activities aimed at protection of air purity and reduction of greenhouse gas emissions from transport have become the priority in the climate and energy policy of the European Union bodies [3,4]. The EU's long-term goal is to achieve such levels of air quality that do not have an unacceptable influence on human health and the environment $[5,6]$. Nevertheless, according to the published report "Air Quality in Europe-2018 report" by the European Environment Agency (EEA), despite the significant reduction levels achieved, air quality in Europe still leaves much to be desired $[7,8]$. One of the main sources of air pollution in the EU is the road transport sector $[9,10]$.

Irrespective of improvements introduced in vehicles and the automotive industry, the road transport sector still has a negative impact on air quality [11,12]. Automobile fumes are much more harmful to people than industrial pollutants, since automotive pollution spreads at high concentrations at low altitudes in the immediate vicinity of people [13,14]. Emissions of substances such as carbon dioxide, carbon monoxide, nitrogen oxides, aromatic hydrocarbons, and harmful substances in the form of solid particles originating from the road transport sector are now significantly higher than they were in 1990 [15-17]. Hence, from time to time, more rigorous limits of exhaust emissions from motor vehicles are introduced $[18,19]$. Additionally, an effort is made towards the design and application of systems and devices for exhaust after-treatment [20,21].

One of the European Parliament's tools in the fight against excessive emissions of air pollutants are the Euro norms $[22,23]$. They define maximum emission values for such substances as hydrocarbons (HC), nitrogen oxides (NOx), carbon monoxide (CO), and particulate matter (PM) [24,25].

Six Euro standards have been created so far which define emission values to the atmosphere,

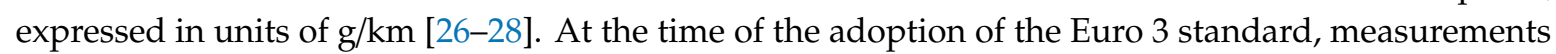


were started using the New European Driving Cycle (NEDC) test consisting of a combination containing parts of urban and extra-urban driving and beginning the moment the engine was started [29,30]. In the Euro 5 and Euro 6 standards, limits for the evolution of particulate matter were also added [31,32]. Regulations are regularly being changed to insure that less and less harmful compounds get into the atmosphere $[33,34]$. They are, however, being introduced gradually to give some time to manufacturers and enable them to create new equipment with ever-better technologies of filtering exhaust gases [35,36]. These activities are the main factor controlling the direction of the development of automotive vehicles $[37,38]$. According to the announced European Union standards in 2021, the average $\mathrm{CO}_{2}$ emission of new cars will not be able to exceed $95 \mathrm{~g} / \mathrm{km}$. Currently, the average standard is $130 \mathrm{~g} \mathrm{CO}_{2} / \mathrm{km}$. Car manufacturers not meeting this requirement will be charged a fine of EUR 95 for each gram of exceedance, calculated for each vehicle sold. This obviously strongly encourages sustainable management of automobile design and production technologies.

Recently, the NEDC test was found to be insufficient for monitoring pollutant emissions from transport [39,40], and the new Worldwide Harmonized Light Duty Vehicles Test Procedure (WLTP) test $[41,42]$ is now being introduced.

From September 2018, car manufacturers may sell new cars under the condition that they meet the new standard of fuel consumption and emissions determined in accordance with the WLTP test standard (there has been a departure from the NEDC test when certifying vehicles for WLTP and real driving emissions (RDE) $[42,43]$. The new regulations also include models of cars that had been approved earlier using the NEDC test and have still not been sold (they must be certified according to the WLTP). Recently, the withdrawal of individual car models and engine versions has occurred numerous times because they did not meet the new rules.

In spite of these restrictive tests, still on the roads of many EU (and in fact not only EU) countries are cars that are about 10 years old and do not meet either the WLTP or the NEDC [44,45] standards.

Determination of the actual emission of pollutants from vehicles was introduced as a result of efforts to reduce the discrepancy between the results of laboratory tests and the results of road tests [46-49]. Devices for emission measurement in real conditions are already widely available [50,51]. Such measurements have become a legal requirement that is valid throughout the EU [52]. The need for further research on the precise determination of the relationship between real emissions from vehicles in road conditions and emissions determined in laboratory conditions is, however, obvious [53-55].

Due to the increasingly stringent emission standards that are applied in Europe, modern cars are equipped with a start/stop system [56,57]. This affects the limitation of the exhaust gas output from the vehicle and also reduces fuel consumption values [58,59]. The concept of operation is simple [60]. When the vehicle is stopped either in a traffic jam or for another reason, the engine is automatically turned off. When the clutch is pressed in a car equipped with a manual transmission or a brake is released in vehicles with automatic transmission, the engine is restarted. The use of such a system has required modifications of some vehicle components [61]. Consequently, testing of new variants of modernized cars is and will be needed. The synchronization of results obtained earlier in conditions required by NEDC tests with the new ones is also of interest. The use of computer simulations may significantly help in the designing of new cars as well as in introducing improvements to the old ones (those for which results of only NEDC tests exist).

In connection with the above, the construction and use of computer simulation models for determining and comparing the values of emitted exhaust components (also in the context of running tests) is not without significance $[62,63]$.

The use of computer simulation as a support in conducted research and development works is being increasingly recognized [64-66]. This has been confirmed by the growing number of scientific articles in which simulations serve as a method for verifying research hypotheses $[67,68]$. Analyzing the term "computer simulation" more comprehensively, the term means the algorithmic method of conducting (using a computer) experiments on dynamic models of existing or designed systems in order to obtain knowledge about the behavior of the system under study [69]. The model is therefore a 
tool which can describe the system and its behavior under various external conditions [70]. In other words, a tool that uses computer simulation to achieve a research goal is a computer program that is a formal representation of the model of the system under investigation [71].

Production and the use of fuels from renewable sources reduces pollution emissions and decreases the dependence of a given country on energy imports from other countries [72-75]. The use for powering car engines of fuel mixtures with various compositions [72], as well as fuels mixed with organic substances (R33 BlueDiesel) [76], also plays a similar role. Thanks to research on the production of low-emission fuels, many studies have been published concerning biofuels, among other types of fuel [77-79]. This issue concerns both methanol, ethanol, and dimethyl ether (DME) [80,81]. Methanol is much cheaper to produce than hydrocarbons and is a better option to reduce the carbon footprint. In addition, it is characterized by better efficiency of fuel processing due to higher steam heating and much better impact resistance [82,83]. Ethanol, in turn, is considered an alternative fuel of limited application, because the calorific value of pure ethyl alcohol is only $60 \%$ of the calorific value of gasoline. It should be taken into account, however, that due to substantial differences in chemical composition between hydrocarbons and alcohols, the combustion of equal volumes of stoichiometric mixtures with the air might give similar amounts of energy, provided that the carburetor is modified for each type of fuel.

Combinations of the aforementioned biofuels with petrol are often used because their small addition does not require any engine modification $[84,85]$. The use of DME as a fuel is also becoming more and more popular due to its economic and ecological benefits as well as favorable physical and chemical properties. A very important aspect regarding methyl esters is the possibility of producing them from biomass [20].

The aim of this work is to investigate the effects of the introduction of biofuels (neat or in a mixture with petrol) on the performance of a standard spark ignition engine. The method of investigation is the application of a computer modeling procedure. Results of computer modelling, when verified with experimental studies, enable performing similar studies for other engines as well as permitting the performance of preliminary analyses prior to designing new engines or modifying old ones. They also enable predictions of the engine and automobile performance when a new fuel is being introduced.

Computer simulations are faster and less expensive than empirical tests and may enable introductory analyses for the cases of technical or technological modifications or just technology transfer.

Good simulation procedures may also serve as a tool for various aspects of technology management in both fuel production technologies as well as technical aspects of engine construction.

Computer simulation of the NEDC or WLTP tests will enable automobile constructors and producers to perform virtual tests of the car while under development or under modification.

Such simulation provides the chance to avoid preliminary investigations of real prototypes, therefore saving time and cost regarding construction works. The present work is aimed towards the investigation of the possibility of simulating results of road tests based on the operational characteristics of the engine. As far as the authors' knowledge is concerned such an approach has not been represented so far in the literature.

\section{Materials and Methods}

The simulation conducted was developed for a city vehicle. It is a small-sized car of low weight which, when combined with the 1.1 Fire engine, guarantees low fuel consumption while providing satisfactory performance [86]. The $1.18 \mathrm{v}$ Fire series engine achieves a maximum power of $54 \mathrm{HP}$ at $5500 \mathrm{rpm}$. The maximum torque is $86 \mathrm{~N} \cdot \mathrm{m}$ at $3800 \mathrm{rpm}$. The stroke and internal diameter are $72 \times 70 \mathrm{~mm}$. The timing gear driven by a belt with one shaft is placed in a head made of aluminum. There are also two valves on each of the four cylinders. The tappets are driven directly. The engine block is made of cast iron and the oil sump is made of steel. The lubrication system with forced circulation uses a gear pump and a full-flow filter. The advantages of this engine include low emissions, 
low fuel consumption, and economical use. Combustion in the mixed cycle is about $5.8 \mathrm{~L} / 100 \mathrm{~km}$, being in the city $(7.2 \mathrm{~L} / 100 \mathrm{~km})$ and in the extra-urban cycle $(4.8 \mathrm{~L} / 100 \mathrm{~km})$.

The analyzed engine was chosen due to the fact that it is one of the most popular engines with low capacity. The torque curve guarantees driving in the city without compromising wear resistance and good performance, thanks to which this engine ranks at the forefront of its category. Models with this engine can be found to be offered by many popular manufacturers.

For the simulation of the selected spark-ignition engine operating in accordance with the NEDC test procedure, the following fuels were used: petrol 95, ethanol, methanol, and DME. The basic parameters of these are presented in Table 2. The demand for fuel in $\mathrm{g} / \mathrm{kWh}$ as a function of the torque dependent upon the angular velocity for the analyzed engine was taken from the results of experimental research published in the literature [87].

Table 2. Basic properties of fuels used [88,89]. Legend: DME, dimethyl ether.

\begin{tabular}{ccccc}
\hline Parameter & Petrol 95 & Ethanol & Methanol & DME \\
\hline Carbon content $[\%]$ & 86.4 & 52.1 & 37.4 & 52.1 \\
Hydrogen content [\%] & 13.6 & 13.1 & 12.5 & 13.1 \\
Oxygen content [\%] & 0.0 & 34.7 & 49.9 & 34.7 \\
Calorific value $[\mathrm{MJ} / \mathrm{kg}]$ & 45.0 & 30.4 & 20.1 & 28.8 \\
Air demand $\left[\mathrm{g}_{\text {air }} / \mathrm{g}_{\text {fuel }}\right]$ & 14.7 & 9.06 & 6.5 & 9.06 \\
\hline
\end{tabular}

In order to calculate the air value that is necessary to burn a specific fuel mixture, the air demand parameters defined for separate components of the mixture were used. The resultant value of the air demand was calculated according to the dependence:

$$
\text { Zap }=(1-u) \cdot Z_{a p_{95}}+u \cdot Z_{a p}{ }_{d}\left[\mathrm{~g}_{\text {air }} / \mathrm{g}_{\text {fuel }}\right]
$$

In successive algorithms of the simulation model to determine the value of the fuel mixture stream generating the same value of flowing chemical energy as in the case of 95 petrol, the calorific value parameters for separate components of the mixture were used. The resultant calorific value was calculated based on the given dependences:

$$
O p=(1-u) \cdot O p_{95}+u \cdot O p_{\mathrm{d}}[\mathrm{kJ} / \mathrm{g}]
$$

To calculate the emissions of carbon dioxide and water vapor, it was necessary to determine the resultant mass fractions of the chemical components carbon, hydrogen, and oxygen.

The NEDC test was introduced to determine the potential environmental pollution by vehicles. Measurements are carried out in a laboratory on a chassis dynamometer, which is designed to recreate actual conditions on roads [90]. The procedure consists of two basic elements: UDC, i.e., urban driving, and EUDC, which reflects driving on a motorway. The completion of a full test allows for the determination of the emissivity of exhaust gases and fuel consumption. Despite the fact that another test has already been introduced-WLTP—-many tests are still being carried out according to the NEDC test [91-94].

The simulation for the vehicle with a spark-ignition engine was carried out in a Scilab simulation environment. Using the $\mathrm{X} \cos$ tool and components thereof, special blocks were created to calculate the searched values $[95,96]$ :

- "Test generator" - this block was responsible for generating signals with precisely determined waveforms that were needed to control the simulation at the time specified for the NEDC test. In this block, the values of vehicle speed $[\mathrm{m} / \mathrm{s}]$ at the given moment and the distance traveled by the vehicle were calculated using the integral element. Calculations of vehicle accelerations were carried out using a differentiating element.

$$
d=\int_{0}^{t k} v(t) d t[m]
$$




$$
a(t)=\frac{d v(t)}{d t}\left[\frac{m}{s^{2}}\right]
$$

Based on the parameters which were specified for running tests and which were adequate for the selected vehicle (conversion weight $740 \mathrm{~kg}$ ), the values of the load resulting from the movement of the vehicle were calculated. In addition to the load associated with the movement resistance of the vehicle, the simulation also calculated the load resulting from the mobility of the driving test. The calculated load values were added up and transferred to subsequent modules. The block also calculated the amount of energy flowing between the vehicle braking rollers. Next, the total energy value transferred to the brake rollers as well as taken from the roller device was calculated. The values calculated during the simulation corresponded adequately to the power and energy transferred by the engine to the load and the power and energy needed to brake the vehicle on the roller stand in the brake system.

- "Drive system"- the elements used in this block took into account at the same time the design diameter of the drive wheels, the actual range of the gear ratios, and the main transmission, allowing the simulation of how the propulsion system in the real vehicle will react. As a result of the calculations, this module transmitted individual signals: speed $[\mathrm{m} / \mathrm{s}]$ — the speed at which the vehicle moves, "Gear speed [rad/s]"- speed [rad/s] of input shaft for the gearbox, and "gear torque $[\mathrm{N} \cdot \mathrm{m}]$ " - torque on the input shaft of the gearbox.

$$
\begin{aligned}
& M p=F k \cdot R \cdot P m[N \cdot m] \\
& \omega p=\frac{v(t)}{R} \cdot P \omega\left[\frac{\mathrm{rad}}{\mathrm{s}}\right]
\end{aligned}
$$

- "Engine"- this module controlled the intervals, in which the torque and speed are changed. This is important because their values cannot be greater than the specified limits of the tested engine model. In this block, the value of the idle speed value of $83.7 \mathrm{rad} / \mathrm{s}(800 \mathrm{rpm})$ corresponding to the principles of the vehicle's engine operation was determined according to the following formulae:

$$
\begin{gathered}
M e=\left|\begin{array}{c}
M p ; M p>83.7 \mathrm{rad} / \mathrm{s} \\
0 \frac{\mathrm{rad}}{\mathrm{s}} ; M p \leq 0 \mathrm{rad} / \mathrm{s}
\end{array}\right|[N \cdot m] \\
\omega e=\left|\begin{array}{c}
\omega p ; \omega p>83.7 \mathrm{rad} / \mathrm{s} \\
83.7 \frac{\mathrm{rad}}{\mathrm{s}} ; \omega p \leq 83.7 \mathrm{rad} / \mathrm{s}
\end{array}\right|\left[\frac{\mathrm{rad}}{\mathrm{s}}\right]
\end{gathered}
$$

The limitation of the engine torque due to the use of the unit fuel consumption characteristic for the selected engine allowed for removal of the negative values of the torque acting on the vehicle's transmission, which corresponded to the braking process of the vehicle in the test by the engine or braking system.

- "Calculations for petrol 95"- based on the adopted characteristics of hourly fuel consumption, this block calculated the instantaneous value of air and fuel enabling engine operation.

$$
\begin{gathered}
\text { fuel }=f u(w e, M e) / 3600\left[\frac{g}{s}\right] \\
\text { air }=\text { fuel.Zap }\left[\frac{g}{s}\right]
\end{gathered}
$$

Taking into account the calorific value of ethyline 95, the energy flow $\dot{E e}[\mathrm{~J} / \mathrm{s}]$ was calculated. In the next stage, the simulation module calculated the temporary values of the motor efficiency $\eta[-]$.

$$
\eta=\frac{M e \cdot \omega e}{\dot{E} e}[-]
$$


The developed simulation included the possibility of running the engine with the start/stop system. In this case, when the start stop system is not turned on, the engine runs throughout the simulation and its demand for fuel and air is calculated as shown above. However, when the start/stop mode is on, the fuel (fuels) and air (airs) streams are calculated from dependencies that enable mathematical consideration of the case of engine shutdown when the vehicle has stopped during the travel test procedure.

$$
\begin{aligned}
& \text { fuels }=\left|\begin{array}{c}
\text { fuel } ; v(t)>0 \mathrm{~m} / \mathrm{s} \\
0 ; v(t)=0 \mathrm{~m} / \mathrm{s}
\end{array}\right|\left[\begin{array}{l}
g \\
s
\end{array}\right] \\
& \text { airs }=\left|\begin{array}{c}
\text { air; } v(t)>0 \mathrm{~m} / \mathrm{s} \\
0 ; v(t)=0 \mathrm{~m} / \mathrm{s}
\end{array}\right|\left[\frac{g}{s}\right] .
\end{aligned}
$$

The simulation component, based on the calculated instantaneous values, performs calculations of cumulative values for the fuel and air consumed over the whole test, using integral elements.

- "Calculations for fuels"-in this segment, the instantaneous consumption of fuel mixtures was calculated based on the calorific values determined in the simulation. The use of air was determined on the basis of the air demand measured in the simulation. Using the calculated proportions of oxygen, carbon, and hydrogen in the fuel mixture, the emission of water vapor and carbon dioxide was calculated. The next step was to determine cumulative values.

$$
\begin{gathered}
\text { fuel }=\frac{\dot{E e}}{O p}\left[\frac{g}{s}\right] \\
\text { air = fuel.Zap }\left[\frac{g}{s}\right]
\end{gathered}
$$

A general outline of the prepared simulation has been presented in the Figure 1. The simulation concerns the operation of the vehicle in accordance with the NEDC test conditions and the use of selected fuels.

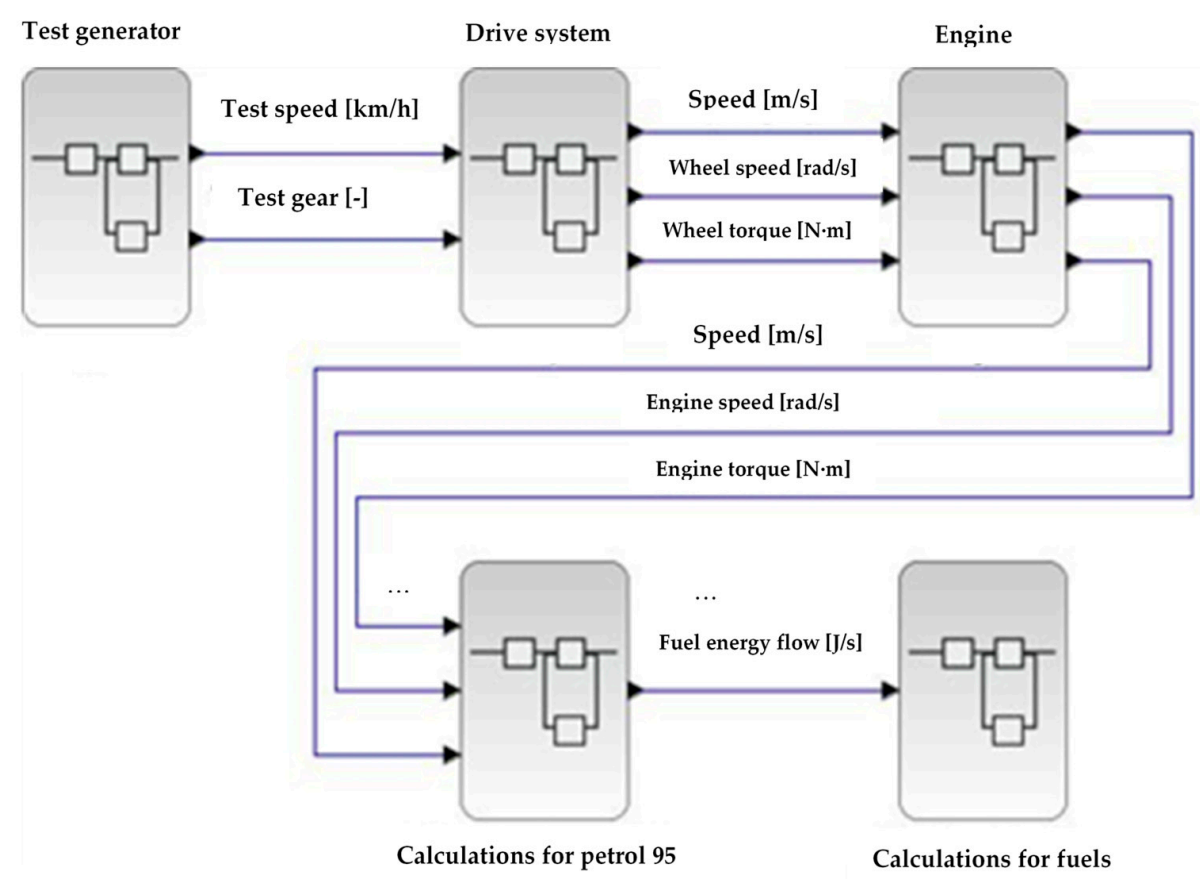

Figure 1. The general scheme of the developed simulation of driving tests for powering the vehicle with fuel mixtures in the Scilab and Xcos environments. 
The block diagram of the conducted simulation for vehicle movement in the road test is shown in Figure 2.

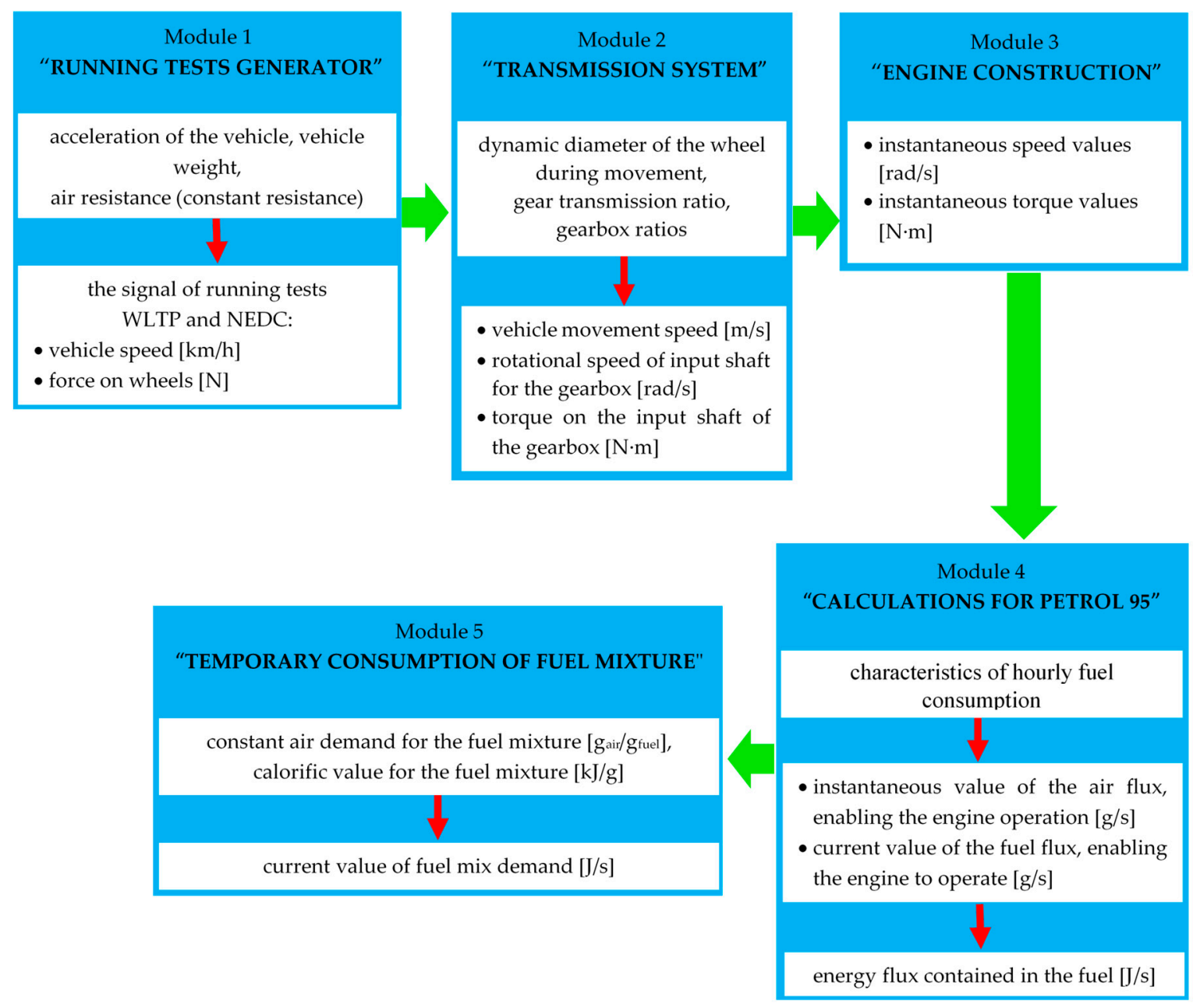

Figure 2. Block diagram of the simulation of running tests for powering the vehicle with fuel mixtures. Legend: WLTP, Worldwide Harmonized Light Duty Vehicles Test Procedure; NEDC, New European Driving Cycle.

\section{Results and Discussion}

The simulated vehicle motion simulation in the NEDC driving test was used to conduct a simulation experiment using different conditions of the start/stop system and when changing the fuel additives and their share in the fuel mixture. Presented below are the results of the simulation work in the form of time-weighted traces and a comparison of fuel consumption parameters, air consumption, and carbon dioxide and water vapor emissions, taking into account the variability of the input parameters of the simulation.

\subsection{Test Generator}

Figure 3 shows the simulation results for the "Test generator" block, which was responsible for producing momentary signals adequate for the NEDC test. The first diagram shows the momentary speed of the vehicle $\mathrm{v}[\mathrm{kph}]$, the cumulative value of the distance travelled by the vehicle $\mathrm{d}[\mathrm{km}]$, the force acting on the vehicle's wheels $\mathrm{F}[\mathrm{N}]$ calculated on the basis of the momentary vehicle speed, the number of the indicated gear in the gearbox $\mathrm{p}[-]$, the course of momentary powers absorbed by the dynamometer during loading of the motor Ph1 [kW], the power of the braking system $\mathrm{Ph} 2[\mathrm{~kW}]$, and the value of energy absorbed Qh1 [MJ] and given off by the simulated chassis dynamometer Qh2 [MJ]. 

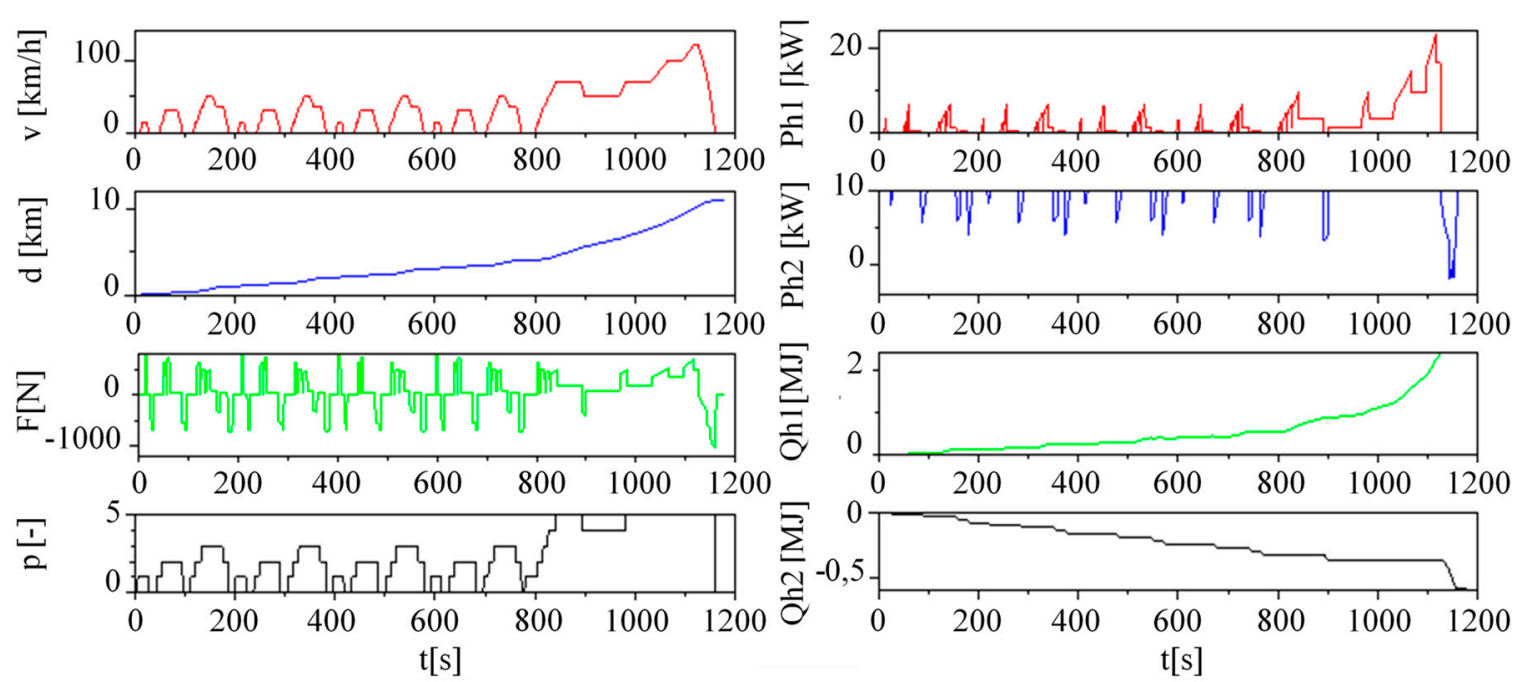

Figure 3. Results of the "Test generator" simulation block responsible for generating NEDC driving test signals.

\subsection{Calculations for Petrol 95 for the Case of the Disabled Start/Stop System}

Figure 4 presents the results of the module "Calculations for petrol 95", as part of the developed simulation for the case of the disabled start/stop system in the form of the momentary waveforms, including motor operation signal (value 1 on, value 0 off), motor angular speed in [rad/s], torque on the Me engine $\left[\mathrm{N}^{*} \mathrm{~m}\right]$, and calculated momentary engine efficiency $n[-]$. The second graph shows the momentary values of the mechanical power produced by the Ne engine [kW], the energy flow from the fuel combustion Nch $[\mathrm{kW}]$, and the course of energy supplied to the engine from the fuel combustion Qch [MJ].
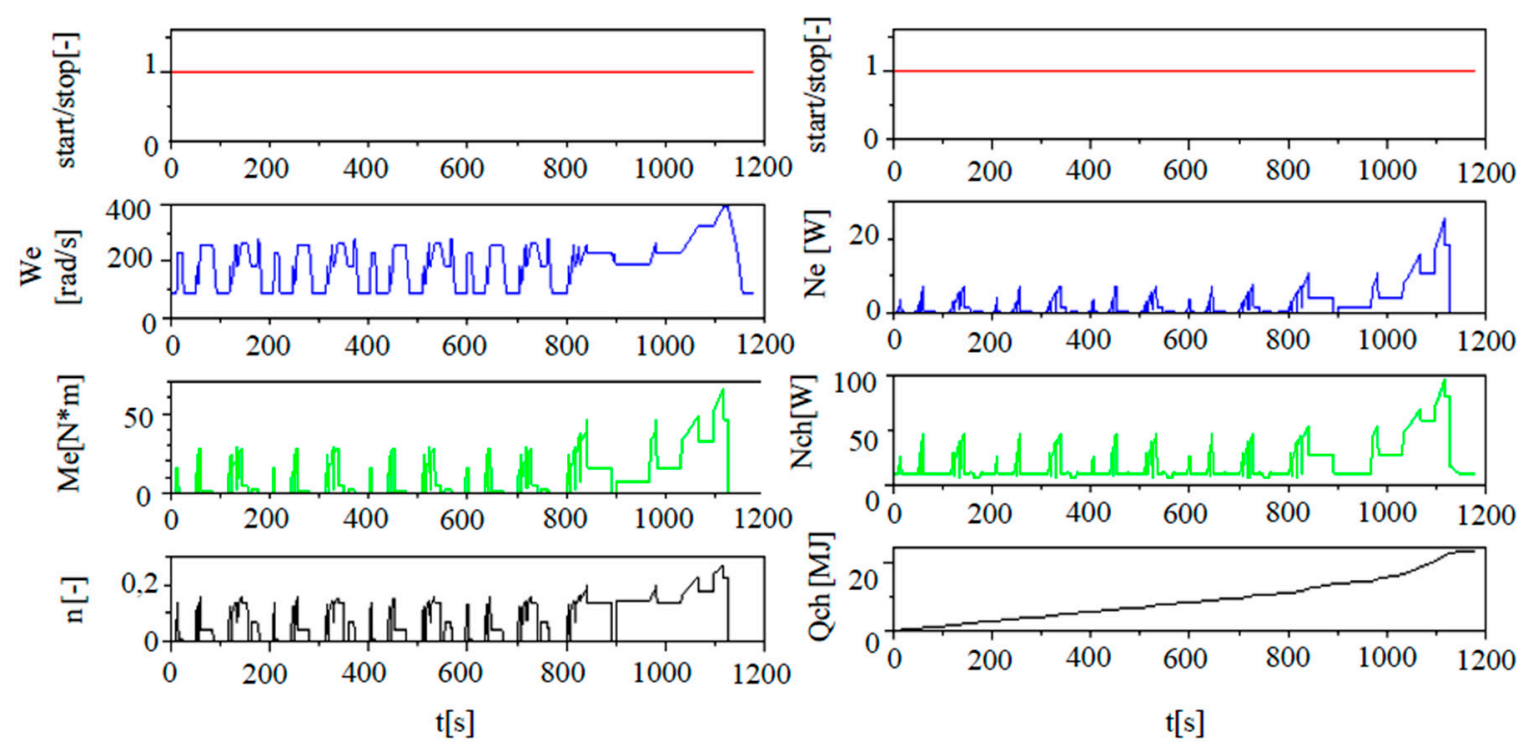

Figure 4. Results of the simulation module "Calculations for petrol 95", which was responsible for the simulation of the engine driven by the applied fuel mixtures; NEDC test, start/stop system disabled.

The analysis of the momentary angular velocity of the engine shows that in cases of vehicle stopping during the simulated driving test, this speed was maintained at $83.7 \mathrm{rad} / \mathrm{s}$ ( $800 \mathrm{rpm}$ ), which corresponds to the idle gear speed for the applied engine. On the other hand, the course of the momentary torque value on the engine indicates zero during stoppage and this is consistent with 
the actual operating conditions of the engine of the vehicle which, does not transmit the drive to further systems.

For the periods when the vehicle is stationary, the tested value of the mechanical power generated by the engine dropped to zero, while the flow of energy supplied to the engine from the fuel combustion was always greater than zero. The consequence of this was that when the vehicle stopped, the engine was running at all times and energy was generated to keep the engine running and to supply energy to other devices built into the vehicle.

The signal visible in Figure 4 is at level 1, which means that the motor simulation module was in operating mode and had a minimum speed of $800 \mathrm{rpm}$ (idling speed). Although the vehicle was standing, the engine was running, i.e., it used fuel and air to maintain the rotational speed (low engine power) and generate a flue gas stream.

The line on graph 9 at level 1 is the equivalent of the simulation technical signal. In the case of simulations taking into account losses/stopping, the value of this signal resulted from checking the condition of whether the car was moving. In the case of driving, the value of 1 forced the engine modules to work on further simulation modules. In the event of a stoppage, the value 0 of this signal caused turning off calculations simulating the work of the engine (the engine has zero speed, no air stream, no exhaust stream).

\subsection{Calculations for Petrol 95 for the Example of the Activated Start/Stop System}

Figure 5 shows the results of the module "Calculations for petrol 95" as part of the developed simulation for the example of the activated start/stop system. In contrast to the previous example of operation without a start/stop system, the values of the momentary angular velocity of the motor for periods of stopping the vehicle during the simulated driving test fell to zero, which was related to switching the engine off. In this case, it can be clearly seen that for the tested periods of vehicle stoppage, the value of the mechanical power generated by the engine dropped to zero and that the flow of energy supplied to the engine from fuel combustion in analogous parts of the simulation also dropped to zero. The consequence of this was that when the vehicle stopped, the engine did not run and the fuel combustion process was stopped.
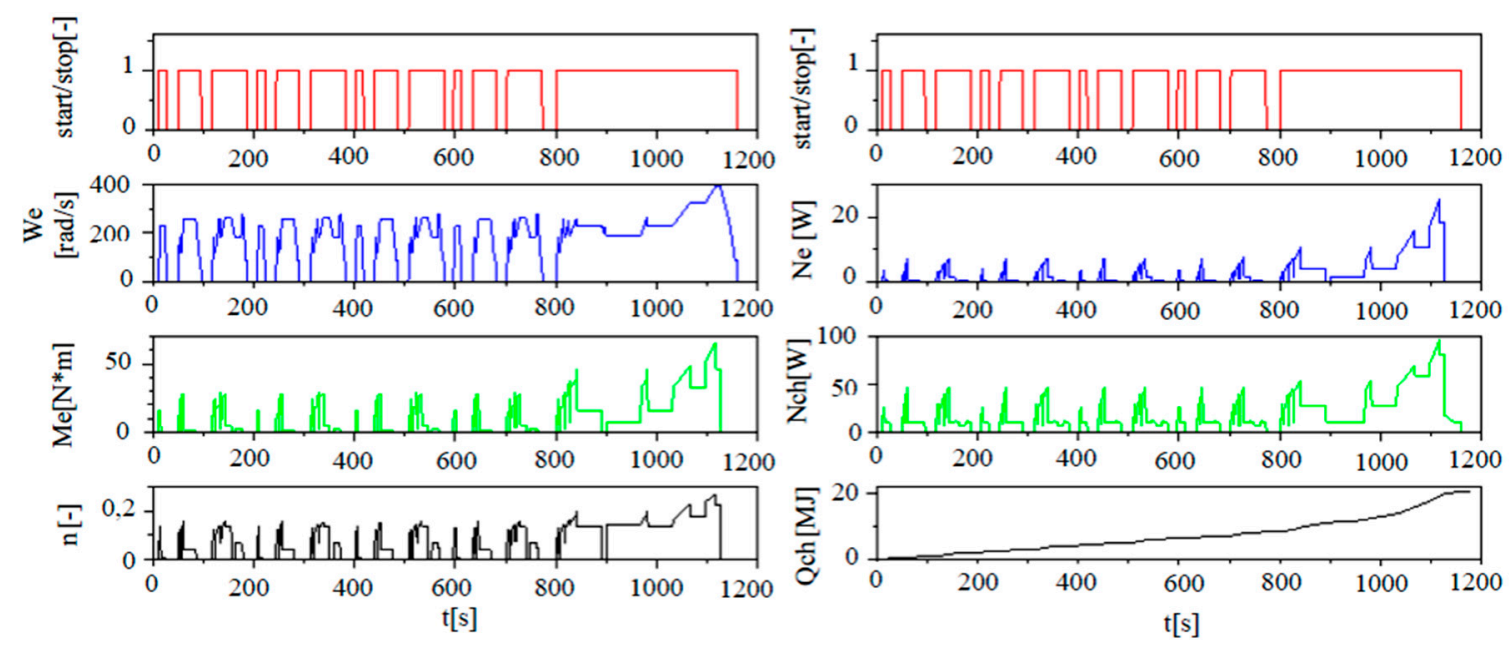

Figure 5. Results of the "Calculations for petrol 95" simulation unit responsible for simulation of the engine driven by the used fuel mixtures; NEDC test, start/stop system enabled.

The simulation of the driving test, compliant with the NEDC test parameters for the selected vehicle, enabled the introduction of modifications of the operating conditions, including start/stop system enabled/disabled, use of various fuels (petrol 95, ethanol, methanol, and DME), and the composition of mixtures of two fuels. 


\subsection{Comparison of Fuel Consumption Changes}

Figure 6 presents a comparison of the fuel consumption changes $[\mathrm{kg}]$ for the conducted simulations of the NEDC test in the function of the additive content [\%] in the used fuel mixture, applying three different additives (ethanol, methanol, and DME).
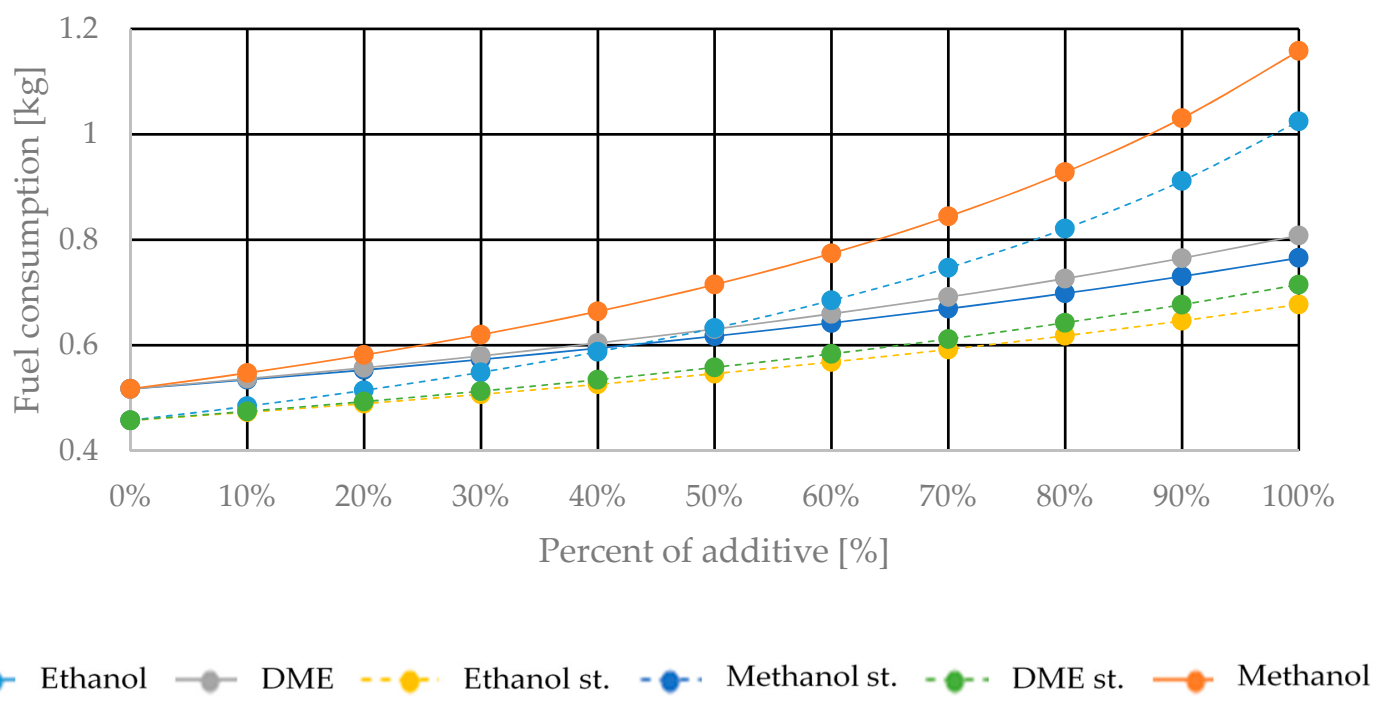

Figure 6. A comparison of the results of the NEDC test simulations under different conditions for fuel consumption for one NEDC cycle [kg] (index "st."-for the enabled start/stop system).

The applied fuel mixtures with minimum shares of additives are characterized by the lowest consumption values. If the proportion of an additive in the mixture increased, the consumption also increased. This increase was due to lower heating values of the additives. In the case of methanol there was a clear and large increase in the mass of the mixture used in the test due to it having the lowest calorific value among all the analyzed fuels. The figure shows two groups of consumption patterns for fuel mixtures: one for the enabled (Ethanol st., Methanol st., DME st.) and one for the disabled (Ethanol, Methanol, DME) start/stop system. The values obtained confirm a significant reduction in the consumption of the mixture of fuels for the same composition.

Figure 7 presents changes in the carbon dioxide emissions [kg] for the fuel mixture used.

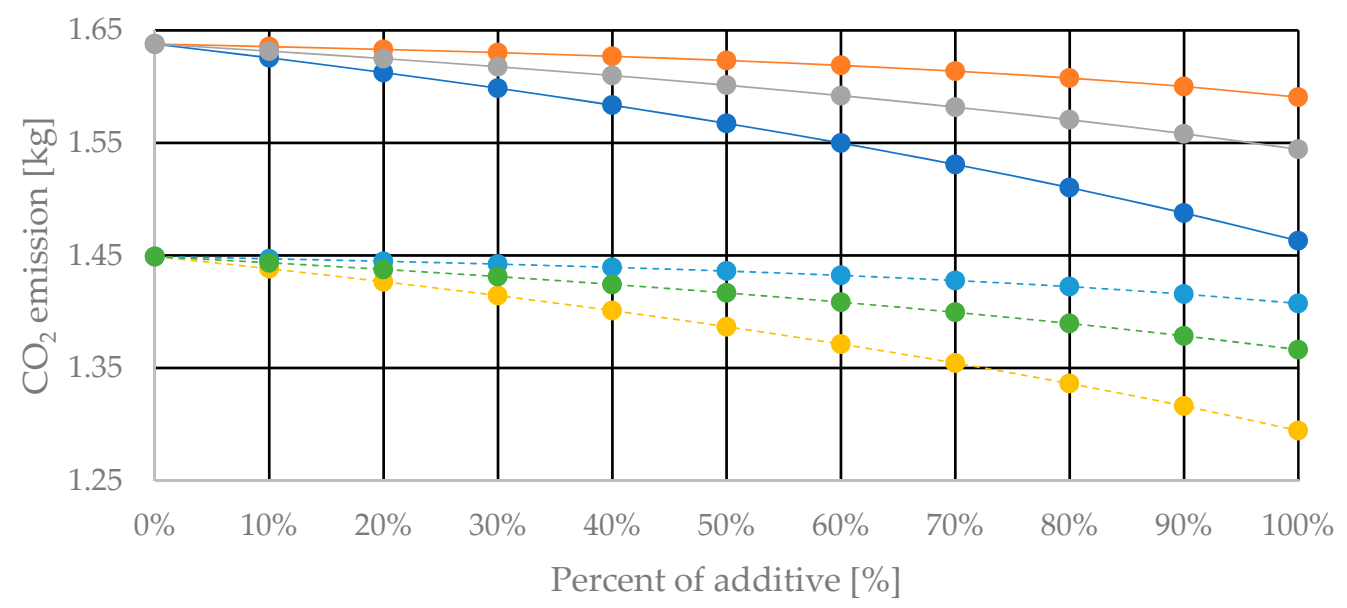

$\longrightarrow$ Ethanol $\rightarrow$ Methanol $\multimap$ DME - - Ethanol st. - - Methanol st. - - DME st.

Figure 7. A comparison of the results of the NEDC test simulations under different conditions for carbon dioxide emissions [kg] (index "st."—for the enabled start/stop system). 
The fuel mixtures used with minimum shares of additives are characterized by the highest values of carbon dioxide emissions. As the proportion of an additive in the mixture increased, the emission decreased slightly because the additives used in their content contained a smaller amount of carbon.

The $\mathrm{CO}_{2}$ emission limit for new passenger cars in the category examined (M1) is currently $130 \mathrm{~g}$ $\mathrm{CO}_{2} / \mathrm{km}$. This level will be reduced to $95 \mathrm{~g} \mathrm{CO}_{2} / \mathrm{km}$ from 2020 .

Compared to the currently applicable standard, all calculated emissions exceeded the permissible threshold by as much as $14 \%$ (the limit in the Euro standard is for $\mathrm{CO}_{2}$ emissions of $130 \mathrm{~g} / \mathrm{km}$ ) (Table 3).

Table 3. Calculated values of carbon dioxide emissions [kg] in NEDC testing.

\begin{tabular}{cccccccccccc}
\hline Additive [\%] & $\mathbf{0 \%}$ & $\mathbf{1 0} \%$ & $\mathbf{2 0} \%$ & $\mathbf{3 0} \%$ & $\mathbf{4 0} \%$ & $\mathbf{5 0} \%$ & $\mathbf{6 0} \%$ & $\mathbf{7 0} \%$ & $\mathbf{8 0} \%$ & $\mathbf{9 0} \%$ & $\mathbf{1 0 0} \%$ \\
\hline Ethanol $[\mathrm{kg}]$ & 1.6378 & 1.6256 & 1.6125 & 1.5985 & 1.5835 & 1.5673 & 1.5498 & 1.5308 & 1.5102 & 1.4877 & 1.4630 \\
Methanol $[\mathrm{kg}]$ & 1.6378 & 1.6356 & 1.6330 & 1.6302 & 1.6269 & 1.6232 & 1.6189 & 1.6137 & 1.6076 & 1.6000 & 1.5907 \\
DME $[\mathrm{kg}]$ & 1.6378 & 1.6360 & 1.6249 & 1.6176 & 1.6098 & 1.6012 & 1.5920 & 1.5818 & 1.5705 & 1.5581 & 1.5443 \\
Ethanol st. [kg] & 1.4490 & 1.4382 & 1.4267 & 1.4143 & 1.4010 & 1.3867 & 1.3712 & 1.3544 & 1.3362 & 1.3162 & 1.2944 \\
Methanol st. [kg] & 1.4490 & 1.4470 & 1.4448 & 1.4423 & 1.4394 & 1.4361 & 1.4323 & 1.4277 & 1.4223 & 1.4156 & 1.4073 \\
DME st. [kg] & 1.4490 & 1.4435 & 1.4376 & 1.4312 & 1.4243 & 1.4167 & 1.4085 & 1.3995 & 1.3895 & 1.3785 & 1.3663 \\
\hline
\end{tabular}

\section{Conclusions}

The production of biofuels and biocomponents is constantly developing. Biofuels and biocomponents are perceived as emission reducers and as fuels to ensure energy security as they are practically inexhaustible. As a result of the tightening of emission standards, it is necessary to modify vehicles and use fuels that produce lower amounts of toxic substances.

The Scilab package used in the work, which graphically presents mathematical algorithms, enabled the development of simulation models for the NEDC test. Based on the analysis of the simulation results, the following conclusions can be postulated:

1. The use of biofuel additives in the air-fuel mixture, due to the molecular structure of these biofuel additives, reduces carbon dioxide emissions and decreases air demand.

2. In the test, all carbon dioxide emissions exceeded the permissible level of $130 \mathrm{~g} \mathrm{CO}_{2} / \mathrm{km}$, which is bad news in the context of the further tightening of standards.

3. In the case of water vapor emissions, a larger share of hydrogen and oxygen in the components used causes the emission to increase.

4. The demand for fuel increases with the increase of the share of biofuel additives. This is due to the lower calorific value of the components.

5. The simulation tests confirmed that in the case of using the start/stop system and applying specific additives, the carbon dioxide emission decreases and the consumption of mixtures with the enabled start/stop system is lower.

The developed simulation model based on the instantaneous value of the vehicle speed in time resulting from the NEDC test calculated the momentary resistance of the vehicle (aerodynamic resistance, rolling resistance) based on the mathematical dependences included in the NEDC standard. On the basis of wheel parameters, the gear ratio of the main gear, and the current required gear number at a given moment (NEDC gears), it was able to calculate the instantaneous value of the engine speed and the torque that the engine must generate. Then, using the universal fuel consumption characteristic for this type of engine (obtained from the literature), the simulation calculated the instantaneous fuel flow. The air stream necessary for the combustion process was calculated using the principle for the gasoline engine to work properly with the stoichiometric composition. Such a simulation solution is a very close process to the real operating conditions of such an engine.

The choice of optimal fuel, i.e., assuring the best performance of engine, and simultaneously connecting it with as clean as possible emissions to the atmosphere, is a real contribution to sustainable transportation. 
It can be also concluded that computer simulations provide useful and good quality technical information faster and in less expensive ways than empirical tests. This enables the application of such simulations to performing analyses of various situations requiring human decisions. The application of computer simulations to decisive processes contributes to the development of tools for technology management, especially that directed towards the development of sustainable economies.

Introduction of the new World Harmonized Light Vehicle) standard stimulates the development of the corresponding algorithm for simulation of these kind of tests. This task requires, however, some work, which will be undertaken in future works.

Author Contributions: Conceptualization, K.T. and R.M.; methodology, O.O. and A.G.; validation, K.B. and A.W.; investigation, O.O. and K.T.; writing—original draft preparation, R.M., A.W., A.G., and K.B.; funding acquisition, A.G.

Funding: The authors wish to express their gratitude to Lublin University of Technology for the financial support given to the present publication (A.G.). The research was carried out under financial support obtained from the research subsidy of the Faculty of Engineering Management (WIZ) of Bialystok University of Technology (O.O. and A.W.).

Conflicts of Interest: The authors declare no conflict of interest. The funders had no role in the design of the study; in the collection, analyses, or interpretation of data; in the writing of the manuscript; or in the decision to publish the results.

\section{References}

1. Meersman, H.; De Voorde, E.V. Freight transport models: Ready to support transport policy of the future? Transp. Policy 2019, in press. [CrossRef]

2. Armeanu, D.Ş.; Vintilă, G.; Gherghina, Ş.C. Does Renewable Energy Drive Sustainable Economic Growth? Multivariate Panel Data Evidence for EU-28 Countries. Energies 2017, 10, 381. [CrossRef]

3. Gherghina, Ş.C.; Onofrei, M.; Vintilă, G.; Armeanu, D.Ş. Empirical Evidence from EU-28 Countries on Resilient Transport Infrastructure Systems and Sustainable Economic Growth. Sustainability 2018, 10, 2900. [CrossRef]

4. Kuklinska, K.; Wolska, L.; Namiesnik, J. Air quality policy in the U.S. and the EU-A review. Atmos. Pollut. Res. 2015, 6, 129-137. [CrossRef]

5. Directive (EU) 2016/2284 of the European Parliament and of the Council of 14 December 2016 on the Reduction of National Emissions of Certain Atmospheric Pollutants, Amending Directive 2003/35/EC and Repealing Directive 2001/81/EC. Available online: https://eur-lex.europa.eu (accessed on 22 March 2019).

6. National Environmental Protection Program until 2020 (with a Prospect Until 2030). Available online: https://www.gov.pl/web/srodowisko (accessed on 22 March 2019).

7. Air Quality in Europe-2018 Report. Available online: https://www.eea.europa.eu (accessed on 22 March 2019).

8. Lehtomäki, H.; Korhonen, A.; Asikainen, A.; Karvosenoja, N.; Kupiainen, K.; Paunu, V.V.; Savolahti, M.; Sofiev, M.; Palamarchuk, Y.; Karppinen, A.; et al. Health Impacts of Ambient Air Pollution in Finland. Int. J. Environ. Res. Public Health 2018, 15, 736. [CrossRef] [PubMed]

9. Pisoni, E.; Christidis, P.; Thunis, P.; Trombetti, M. Evaluating the impact of "Sustainable Urban Mobility Plans" on urban background air quality. J. Environ. Manag. 2019, 231, 249-255. [CrossRef]

10. Santos, F.M.; Gómez-Losada, A.; Pires, J.C.M. Impact of the implementation of Lisbon low emission zone on air quality. J. Hazard. Mater. 2019, 365, 632-641. [CrossRef] [PubMed]

11. Cleaner Air for all. Available online: http://ec.europa.eu/environment/air/cleaner_air/ (accessed on 15 May 2019).

12. Jiménez, J.L.; Valido, J.; Molden, N. The drivers behind differences between official and actual vehicle efficiency and $\mathrm{CO}_{2}$ emissions. Transp. Res. Part D Transp. Environ. 2019, 67, 628-641. [CrossRef]

13. Bukrejewski, P.; Skolniak, M.; Kowalski, Ł. Comparison of the environmental effect of M1 category vehicles fed with traditional and alternative fuels. Arch. Automot. Eng. 2017, 75, 5-21.

14. Kuranc, C. Emission of the fume's harmful components in the control tests upon the chosen population of vehicles. Autobusy 2011, 10, 1-9.

15. Landscape Review: EU Action on Energy and Climate Change. Available online: https://www.eca.europa. eu/en/Pages/DocItem.aspx?did=41824 (accessed on 22 March 2019). 
16. Motowidlak, U. Role of urban transport towards achieving a low-carbon economy. Studia Ekonomiczne 2015, 249, 172-184.

17. TERM 2015: Transport Indicators Tracking Progress Towards Environmental Targets in Europe. EEA Report 7/2015. Available online: https://www.ecologic.eu/13108 (accessed on 22 March 2019).

18. Bielaczyc, P.; Szczotka, A.; Pajdowski, P.; Woodburn, J. The potential of current European light duty LPG-fuelled vehicles to meet Euro 6 requirement. Combust. Engines 2015, 162, 874-880.

19. O'Driscoll, R.; Stettler, M.E.J.; Molden, N.; Oxley, T.; ApSimon, H.M. Real world $\mathrm{CO}_{2}$ and NOx emissions from 149 Euro 5 and 6 diesel, gasoline and hybrid passenger cars. Sci. Total Environ. 2018, 621, $282-290$. [CrossRef]

20. Flekiewicz, M.; Kubica, G. The use of gaseous fuels mixtures for SI engines propulsion. IOP Conf. Ser. Mater. Sci. Eng. 2016, 148, 1-11. [CrossRef]

21. Iliev, S. A comparison of ethanol and methanol blending with gasoline using a 1-D engine model. Procedia Eng. 2015, 100, 1013-1022. [CrossRef]

22. Costagliola, M.A.; Costabile, M.; Prati, M.V. Impact of road grade on real driving emissions from two Euro 5 diesel vehicles. Appl. Energy 2018, 231, 586-593. [CrossRef]

23. Weber, C.; Sundvor, I.; Figenbaum, E. Comparison of regulated emission factors of Euro 6 LDV in Nordic temperatures and cold start conditions: Diesel- and gasoline direct-injection. Atmos. Environ. 2019, 206, 208-217. [CrossRef]

24. Grigoratos, T.; Fontaras, G.; Giechaskiel, B.; Zacharof, N. Real world emissions performance of heavy-duty Euro VI diesel vehicles. Atmos. Environ. 2019, 201, 348-359. [CrossRef]

25. Puškár, M.; Kopas, M. System based on thermal control of the HCCI technology developed for reduction of the vehicle NOX emissions in order to fulfil the future standard Euro 7. Sci. Total Environ. 2018, 643, 674-680. [CrossRef]

26. Hooftman, N.; Oliveira, L.; Messagie, M.; Coosemans, T.; Van Mierlo, J. Environmental Analysis of Petrol, Diesel and Electric Passenger Cars in a Belgian Urban Setting. Energies 2016, 9, 84. [CrossRef]

27. Lv, W.; Hu, Y.; Li, E.; Liu, H.; Pan, H.; Ji, S.; Hayat, T.; Alsaedi, A.; Ahmad, B. Evaluation of vehicle emission in Yunnan province from 2003 to 2015. J. Clean. Prod. 2019, 207, 814-825. [CrossRef]

28. Mendoza-Villafuerte, P.; Suarez-Bertoa, R.; Giechaskiel, B.; Riccobono, F.; Bulgheroni, C.; Astorga, C.; Perujo, A. NOx, $\mathrm{NH}_{3}, \mathrm{~N}_{2} \mathrm{O}$ and $\mathrm{PN}$ real driving emissions from a Euro VI heavy-duty vehicle. Impact of regulatory on-road test conditions on emissions. Sci. Total Environ. 2017, 609, 546-555. [CrossRef]

29. Ramos, A.; Muñoz, J.; Andrés, F.; Armas, O. NOx emissions from diesel light duty vehicle tested under NEDC and real-word driving conditions. Transp. Res. Part D Transp. Environ. 2018, 63, 37-48. [CrossRef]

30. Implementation of the NEDC/WLTP Correlation Procedures for Cars and Light Commercial Vehicles. Available online: https://ec.europa.eu/clima/ (accessed on 15 May 2019).

31. Louis, C.; Liu, Y.; Martinet, S.; D'Anna, B.; Valiente, A.M.; Boreave, A.; R'Mili, B.; Tassel, P.; Perret, P.; André, M. Dilution effects on ultrafine particle emissions from Euro 5 and Euro 6 diesel and gasoline vehicles. Atmos. Environ. 2017, 169, 80-88. [CrossRef]

32. Mamakos, A.; Martini, G.; Manfredi, U. Assessment of the legislated particle number measurement procedure for a Euro 5 and a Euro 6 compliant diesel passenger cars under regulated and unregulated conditions. J. Aerosol Sci. 2013, 55, 31-47. [CrossRef]

33. Huang, Y.; Ng, E.C.Y.; Yam, Y.; Lee, C.K.C.; Surawski, N.C.; Mok, W.; Organ, B.; Zhou, J.L.; Chan, E.F.C. Impact of potential engine malfunctions on fuel consumption and gaseous emissions of a Euro VI diesel truck. Energy Convers. Manag. 2019, 184, 521-529. [CrossRef]

34. Xu, G.; Jia, M.; Li, Y.; Chang, Y.; Wang, T. Potential of reactivity controlled compression ignition (RCCI) combustion coupled with variable valve timing (VVT) strategy for meeting Euro 6 emission regulations and high fuel efficiency in a heavy-duty diesel engine. Energy Convers. Manag. 2018, 171, 683-698. [CrossRef]

35. ECOpoint. Diesel Emissions Online. Available online: https://www.dieselnet.com (accessed on 22 March 2019).

36. Czapliński, E.; Idzior, M. The research into the influence of the technical condition of motor vehicles in operation on exhaust pollutant emissions. Combust. Engines 2015, 54, 578-581.

37. Laboratories \& Facilities. Available online: https://ec.europa.eu/jrc/en/research-facilities (accessed on 15 May 2019).

38. Triantafyllopoulos, G.; Dimaratos, A.; Ntziachristos, L.; Bernard, Y.; Dornoff, J.; Samaras, Z. A study on the $\mathrm{CO}_{2}$ and NOx emissions performance of Euro 6 diesel vehicles under various chassis dynamometer and on-road conditions including latest regulatory provisions. Sci. Total Environ. 2019, 666, 337-346. [CrossRef] 
39. Liu, Q.; Liu, J.; Fu, J.; Li, Y.; Luo, B.; Zhan, Z.; Deng, B. Comparative study on combustion and thermodynamics performance of gasoline direct injection (GDI) engine under cold start and warm-up NEDC. Energy Convers. Manag. 2019, 181, 663-673. [CrossRef]

40. Ma, R.; He, X.; Zheng, Y.; Zhou, B.; Lu, S.; Wu, Y. Real-world driving cycles and energy consumption informed by large-sized vehicle trajectory data. J. Clean. Prod. 2019, in press. [CrossRef]

41. EU Project GasOn n.652816. Available online: https://ec.europa.eu/jrc/en/publication/eu-project-gasonn652816 (accessed on 15 May 2019).

42. Pavlovic, J.; Marotta, A.; Ciuffo, B. $\mathrm{CO}_{2}$ emissions and energy demands of vehicles tested under the NEDC and the new WLTP type approval test procedures. Appl. Energy 2016, 177, 661-670. [CrossRef]

43. Blanco-Rodriguez, D.; Vagnoni, G.; Holderbaum, B. EU6 C-Segment Diesel vehicles, a challenging segment to meet RDE and WLTP requirements. IFAC PapersOnLine 2016, 49, 649-656. [CrossRef]

44. Mathissen, M.; Grochowicz, J.; Schmidt, C.; Vogt, R.; Farwick zum Hagen, F.H.; Grabiec, T.; Steven, H.; Grigoratos, T. A novel real-world braking cycle for studying brake wear particle emissions. Wear 2018, 414-415, 219-226. [CrossRef]

45. Dzikuć, M.; Adamczyk, J.; Piwowar, A. Problems associated with the emissions limitations from road transport in the Lubuskie Province (Poland). Atmos. Environ. 2017, 160, 1-8. [CrossRef]

46. Cha, J.; Lee, J.; Chon, M.S. Evaluation of real driving emissions for Euro 6 light-duty diesel vehicles equipped with LNT and SCR on domestic sales in Korea. Atmos. Environ. 2019, 196, 133-142. [CrossRef]

47. Wang, Y.; Xing, Z.; Xu, H.; Du, K. Emission factors of air pollutants from CNG-gasoline bi-fuel vehicles: Part I. Black carbon. Sci. Total Environ. 2016, 572, 1161-1165. [CrossRef] [PubMed]

48. Degraeuwe, B.; Weiss, M. Does the New European Driving Cycle (NEDC) really fail to capture the NOX emissions of diesel cars in Europe? Environ. Pollut. 2017, 222, 234-241. [CrossRef] [PubMed]

49. Pavlovic, J.; Anagnostopoulos, K.; Clairotee, M.; Arcidiacono, V.; Fontaras, G.; Rujas, I.P.; Morales, V.V.; Ciuffo, B. Dealing with the Gap between Type-Approval and In-Use Light Duty Vehicles Fuel Consumption and $\mathrm{CO}_{2}$ Emissions: Present Situation and Future Perspective. Transp. Res. Rec. J. Transp. Res. Board 2018, 2672, 23-32. [CrossRef]

50. Suarez-Bertoa, R.; Kousoulidou, M.; Clairotte, M.; Giechaskiel, B.; Nuottimäki, J.; Sarjovaara, T.; Lonza, L. Impact of HVO blends on modern diesel passenger cars emissions during real world operation. Fuel 2019, 235, 1427-1435. [CrossRef]

51. Fontaras, G.; Zacharof, N.G.; Ciuffo, B. Fuel consumption and $\mathrm{CO}_{2}$ emissions from passenger cars in Europe-Laboratory versus real-world emissions. Prog. Energy Combust. Sci. 2017, 60, 97-131. [CrossRef]

52. Dimaratos, A.; Tsokolis, D.; Fontaras, G.; Tsiakmakis, S.; Ciuffo, B.; Samaras, Z. Comparative Evaluation of the Effect of Various Technologies on Light-duty Vehicle $\mathrm{CO}_{2}$ Emissions over NEDC and WLTP. Transp. Res. Procedia 2016, 14, 3169-3178. [CrossRef]

53. Bielaczyc, P.; Woodburn, J. Trends in Automotive emissions, fuels, lubricants, legislation and test methods-Present and future. A brief overview from the perspective of the International Organising Committee of the 4th International Emissions Symposium. Combust. Engines 2014, 3, 93-100.

54. Wójcik, W.; Adikanova, S.; Malgazhdarov, Y.A.; Nabenovich, M.M.; Myrzagalieva, A.B.; Temirbekov, N.M.; Junisbekov, M.; Pawłowski, L. Probabilistic and Statistical Modelling of the Harmful Transport Impurities in the Atmosphere from Motor Vehicles. Rocznik Ochrona Środowiska 2017, 19, 795-808.

55. Hooftman, N.; Messagie, M.; Van Mierlo, J.; Coosemans, T. A review of the European passenger car regulations-Real driving emissions vs local air quality. Renew. Sustain. Energy Rev. 2018, 86, 1-21. [CrossRef]

56. Zhang, T.; Wang, P.; Chen, H.; Pei, P. A review of automotive proton exchange membrane fuel cell degradation under start-stop operating condition. Appl. Energy 2018, 223, 249-262. [CrossRef]

57. Fonseca, N.; Casanova, J.; Valdés, M. Influence of the stop/start system on $\mathrm{CO}_{2}$ emissions of a diesel vehicle in urban traffic. Transp. Res. Part D Transp. Environ. 2011, 16, 194-200. [CrossRef]

58. Ibarra, D.; Ramirez-Mendoza, R.A.; López, E.; Bustamante, R. Influence of the automotive Start/Stop system on noise emission: Experimental study. Appl. Acoust. 2015, 100, 55-62. [CrossRef]

59. Ji, C.; Yu, M.; Wang, S.; Zhang, B.; Cong, X.; Feng, Y.; Lin, S. The optimization of on-board $\mathrm{H}_{2}$ generator control strategy and fuel consumption of an engine under the NEDC condition with start- stop system and H2 start. Int. J. Hydrogen Energy 2016, 41, 19256-19264. [CrossRef] 
60. Ozdemir, A.; Mugan, A. Stop/Start System Integration to Diesel Engine and System Modelling \& Validation. IFAC Proc. Vol. 2013, 46, 95-100.

61. Do Stop-Start Systems Really Save Fuel? Available online: https://www.edmunds.com (accessed on 22 March 2019).

62. Tsiakmakis, S.; Fontarasa, G.; Anagnostopoulos, K.; Ciuffo, B.; Pavlovic, J.; Marotta, A. A simulation based approach for quantifying $\mathrm{CO}_{2}$ emissions of light duty vehicle fleets. A case study on WLTP introduction. Transp. Res. Procedia 2017, 25, 3898-3908. [CrossRef]

63. Ciuffo, B.; Fontaras, G. Models and scientific tools for regulatory purposes: The case of $\mathrm{CO}_{2}$ emissions from light duty vehicles in Europe. Energy Policy 2017, 109, 76-81. [CrossRef]

64. Guo, H.; Cao, D.; Chen, H.; Sun, Z.; Hu, Y. Model predictive path following control for autonomous cars considering a measurable disturbance: Implementation, testing, and verification. Mech. Syst. Signal Process. 2019, 118, 41-60. [CrossRef]

65. Su, G.; Li, N.; Yildiz, Y.; Girard, A.; Kolmanovsky, I. A Traffic Simulation Model with Interactive Drivers and High-fidelity Car Dynamics. IFAC PapersOnLine 2019, 51, 384-389. [CrossRef]

66. Martynov, S.B.; Mason, D.J.; Heikal, M.R. Numerical Simulation of Cavitation Flows Based on Their Hydrodynamic Similarity. Int. J. Engine Res. 2006, 7, 283-296. [CrossRef]

67. Mai, M.; Wang, L.; Prokop, G. Advancement of the car following model of Wiedemann on lower velocity ranges for urban traffic simulation. Transp. Res. Part F Traffic Psychol. Behav. 2019, 61, 30-37. [CrossRef]

68. Illgen, S.; Höck, M. Electric vehicles in car sharing networks-Challenges and simulation model analysis. Transp. Res. Part D Transp. Environ. 2018, 63, 377-387. [CrossRef]

69. Markowski, A. Application of discrete event simulation algorithms for evaluation of data transmission delay in distributed measuring and control system. Przeglad Elektrotechniczny 2018, 94, 21-25.

70. Campbell, T.; Owhadi, H.; Sauvageau, J.; Watkinson, D. On Testing the Simulation Theory. Int. J. Quantum Found. 2017, 3, 78-99.

71. Łatuszyńska, M. Computer simulation in exprimental economics. Zeszyty Naukowe Uniwersytetu Sczecińskiego 2015, 36, 1-14. [CrossRef]

72. Firmansyah; Aziz, A.A.R.; Heikal, M.R.; Zainal A., Ezrann Z.; Ezrann Z. Zainal, A. Zainal A. Diesel/CNG Mixture Autoignition Control Using Fuel Composition and Injection Gap. Energies 2017, 10, 1639. [CrossRef]

73. Convery, F.; Ferreira, S.; Ryan, L.B. Stimulating the use of biofuels in the European Union: Implications for climate change policy. Energy Policy 2006, 34, 3184-3194.

74. Directive 2009/28/EC of the European Parliament and of the Council of 23 April 2009 on the Promotion of the Use of Energy from Renewable Sources and Amending and Subsequently Repealing Directives 2001/77/EC and 2003/30/EC. Available online: https://eur-lex.europa.eu (accessed on 22 March 2019).

75. Jakubowski, W.; Wituszyński, K.P. Analysis of the zi engines cars exhaust-gas toxicity in the light of valid traffic regulations. Acta Mechanica et Automatica 2009, 3, 98-100.

76. The New R33 BlueDiesel Fuel with a Component from Renewable Sources. Available online: https: //www.greencarcongress.com (accessed on 20 March 2019).

77. Tucki, K.; Bączyk, A.; Klimkiewicz, M.; Mączyńska, J.; Sikora, M. Comparison of parameters and composition of exhaust fumes of engine fuelled by rapeseed oil and its mixtures with diesel and gasoline. In Proceedings of the 2nd International Conference on the Sustainable Energy and Environmental Development (SEED'17), Kraków, Poland, 14 November 2017; Volume 214, pp. 1-9.

78. Dafnomilis, I.; Hoefnagels, R.; Pratama, Y.W.; Schott, D.L.; Lodewijks, G.; Junginger, M. Review of solid and liquid biofuel demand and supply in Northwest Europe towards 2030-A comparison of national and regional projections. Renew. Sustain. Energy Rev. 2017, 78, 31-45. [CrossRef]

79. Green Fuels and Human Health Toxicity of Engine Emission from 1st and 2nd Generation Biodiesel Fuels Pol-Nor/201040/72/2013. Available online: http://www.fuelhealth.eu (accessed on 16 March 2019).

80. El-Faroug, M.O.; Yan, F.; Luo, M.; Turkson, R.F. Spark ignition engine combustion, performance and emission products from hydrous ethanol and its blends with gasoline. Energies 2016, 9, 984. [CrossRef]

81. Azadi, P.; Malina, R.; Barrett, S.R.H.; Kraft, M. The evolution of the biofuel science. Renew. Sustain. Energy Rev. 2017, 76, 1479-1484. [CrossRef]

82. Kupczyk, A.; Mączyńska, J.; Sikora, M.; Tucki, K.; Żelaziński, T. Stan i perspektywy oraz uwarunkowania prawne funkcjonowania sektorów biopaliw transportowych w Polsce. Roczniki Naukowe Ekonomii Rolnictwa $i$ Rozwoju Obszarów Wiejskich 2017, 104, 39-55. [CrossRef] 
83. Jung, S.; Leng, Y.; Wang, C.Y. Role of $\mathrm{CO}_{2}$ in Methanol and Water Transport in Direct Methanol Fuel Cells. Electrochim. Acta 2014, 134, 35-48. [CrossRef]

84. Flekiewicz, M.; Kubica, G.; Marzec, P. The possibilities of using DME (BioDME), as an additive to conventional gaseous fuels in SI engine. Combust. Engines 2017, 171, 150-155.

85. Ghazal, O.H. A theoretical study of the SI engine performance operating with different fuels. Int. J. Mech. Mechatron. Eng. 2013, 7, 1-4.

86. Zembowicz, J. Fiat Seicento, 1st ed.; Wydawnictwo Komunikacji i Łączności: Warsaw, Poland, 2010; pp. 10-220.

87. Romaniszyn, K.M. Evaluation of the differences in determining fuel consumption for a real car based on universal and dynamic characteristics. Combust. Engines 2002, 2, 48-54.

88. Dobras, S.; Więcław-Solny, L.; Chwoła, T.; Krótki, A.; Wilk, A.; Tatarczuk, A. Renewable methanol as a fuel and feedstock in the chemical industry. Zeszyty Naukowe Instytutu Gospodarki Surowcami Mineralnymi $i$ Energia PAN 2017, 98, 27-37.

89. Kordylewski, W. Spalanie i Paliwa, 4th ed.; Oficyna Wydawnicza Politechniki Wrocławskiej: Wroclaw, Poland, 2005; pp. 79-433.

90. Bajerlein, M.; Dobrzyński, M.; Fuć, P.; Lijewski, P.; Merkisz, J.; Ziółkowski, A.; Rymaniak, Ł. Exhaust emission in NEDC test simulated at a dynamic engine test bed. Combust. Engines 2013, 52, 701-707.

91. Botwińska, K.; Mruk, R.; Słoma, J.; Tucki, K.; Zaleski, M. Simulation of diesel engine emissions on the example of Fiat Panda in the NEDC test. In Proceedings of the E3S Web Conference 2017, Polanica Zdrój, Poland, 13-15 September 2017; Volume 19, pp. 1-6.

92. Mazanek, A. An overview of engine and exploitation research methods taking into account the current and future quality requirements on motor fuels. Nafta Gaz 2014, 70, 534-540.

93. Botwińska, K.; Mruk, R.; Tucki, K.; Wata, M. Simulation of fuel demand for wood-gas in combustion engine. In Proceedings of the E3S Web Conference 2017, Polanica Zdrój, Poland, 13-15 September 2017; Volume 19, pp. 1-6.

94. Zhu, G.; Liu, J.; Fu, J.; Xu, Z.; Guo, Q.; Zhao, H. Experimental study on combustion and emission characteristics of turbocharged gasoline direct injection (GDI) engine under cold start new European driving cycle (NEDC). Fuel 2018, 215, 272-284. [CrossRef]

95. Campbell, S.L.; Chancelier, J.P.; Nikoukhah, R. Modeling and Simulation in Scilab/Scicos with ScicosLab 4.4, 1st ed.; Springer: New York, NY, USA, 2006; pp. 73-155.

96. Tucki, K.; Mruk, R.; Bączyk, A.; Botwińska, K.; Woźniak, K. Analysis of the Exhaust Gas Emission Level from a Diesel Engine with Using Computer Simulation. Rocznik Ochrona Środowiska 2018, 20, 1095-1112. 